\title{
EKSTRAK ETIL ASETAT DAUN JAMBU BIJI MERAH (PSIDIUM GUA) AVA L.) SEBAGAI ANTIOKSIDAN SECARA IN VITRO
}

\author{
Ethyl Acetate Extract of Red Guava Leaves (Psidium guajava L.) As An \\ Antioxidant In Vitro
}

\author{
Jihan Farah, Yuliar, Mauritz Pandapotan Marpaung
}

Fakultas Farmasi, Universitas Kader Bangsa (UKB)

Jalan Mayjen. H.M. Ryacudu No.88, 8 Ulu, Seberang Ulu I, Palembang, Sumsel 30111

Email: jihanfarah82@gmail.com

085270198900

\begin{abstract}
This study aimed to find out antioxidant activity extract of guava leaves (Psidium gujava L.). Leaf extract of guava (Psidium gujava L.) was extracted by maceration with ethyl acetate solvent. Antioxidant activity test was tested by DPPH (2,2-Diphenyl-1Picrylhidrazil) method with quercetin as positive control. Antioxidants are determined by testing against DPPH free radicals by measuring the absorbance of DPPH at wavelength of $516 \mathrm{~nm}$. The result of antioxidant activity showed that IC50 value at ethyl acetate was $37.39 \mathrm{ppm}$ (very strong) and the quercetin was $0.562 \mathrm{ppm}$ (very strong). Based on the results of antioxidant analysis, it was found that the ethyl acetate extract of guava leaves had very strong antioxidant activity.
\end{abstract}

Kaywords: Guava leaf, antioxidants, $D P P H$, quercetin.

\begin{abstract}
Abstrak
Penelitian ini bertujuan untuk mengetahui aktivitas antioksidan ekstrak daun jambu biji (Psidium gujava L.). Ekstrak daun jambu biji (Psidium gujava L.) diekstraksi secara maserasi dengan pelarut etil asetat. Uji aktivitas antioksidan diuji dengan metode DPPH (2,2-Diphenyl-1-Picrylhidrazil) dengan kuersetin sebagai kontrol positif. Antioksidan ditentukan dengan menguji terhadap radikal bebas DPPH dengan mengukur absorbansi DPPH pada panjang gelombang $516 \mathrm{~nm}$. Hasil aktivitas antioksidan menunjukkan bahwa nilai $\mathrm{IC}_{50}$ pada etil asetat adalah 37,39 ppm (sangat kuat). dan kuersetin sebesar $0,562 \mathrm{ppm}$ (sangat kuat). Berdasarkan hasil analisis antioksidan diperoleh bahwa ekstrak etil asetat daun jambu biji memiliki aktivitas antioksidan sangat kuat.
\end{abstract}

Kata kunci: Jambu biji, antioksidan, DPPH, kuersetin.

\section{PENDAHULUAN}

Indonesia yang beriklim tropis menyebabkan tanaman subur sehingga banyak jenis tumbuhan yang dapat tumbuh. Di antara berbagai jenis tumbuhan tersebut memiliki khasiat sebagai obat, salah satunya adalah jambu biji merah (Psidium guajava L.). Daun jambu biji di Indonesia dijadikan obat alternatif terhadap berbagai penyakit sangat besar. Hal ini disebabkan karena ada beberapa senyawa kimia yang terkandung dalam 
daun jambu biji yaitu senyawa polifenol, karoten, flavonoid dan tanin. Polifenol yang ditemukan pada daun diketahui memiliki aktivitas antioksidan [1].

Kandungan senyawa fenolik seperti flavonoid, turunan kumarin dan lainnya yang terkandung di dalam bahan tanaman tertentu diketahui dapat menangkal stres oksidatif di tubuh manusia dengan cara membantu mempertahankan keseimbangan antara oksidan dan antioksidan. Stres oksidatif adalah keadaan ketika kandungan oksidan dan radikal bebas di dalam tubuh lebih banyak dibandingkan antioksidan [2].

Pada hasil penelitian tentang daun jambu biji yang diekstraksi dengan metode maserasi menggunakan pelarut etanol menunjukkan kekuatan aktivitas antioksidan yang baik [3]. Antioksidan adalah senyawa kimia yang dapat menyumbangkan satu atau lebih elektron kepada radikal bebas, sehingga dapat diredam [4]. Penggunaan antioksidan sintetik mulai dibatasi karena ternyata penggunaan antioksidan sintetik seperti butylated hydroxytoluen (BHT), butylated hydroxyanisole (BHA), dan tertbutylhydroxy quinone (TBHQ) telah dibatasi pada produk-produk makanan karena dianggap memiliki efek karsinogenik. Hal ini yang mendorong berbagai penelitian untuk menemukan sumber antioksidan baru yang berasal dari alam yang diharapkan dapat mengganti antioksidan sintetik [5].

Salah satu uji untuk menentukan aktivitas antioksidan penangkap radikal adalah metode DPPH (2,2 Difenil-1Pikrilhidrazi). Metode ini merupakan uji untuk menentukan aktivitas antioksidan dalam sampel yang dalam menangkap radikal bebas DPPH. Sumber radikal bebas dari metode ini adalah senyawa 2,2 Difenil-1-Pikrilhidrazil (DPPH) [6].
Dalam penelitian ini, metode ekstraksi yang digunakan adalah metode maserasi dengan menggunakan pelarut etil asetat. Pelarut etil asetat merupakan pelarut semi-polar yang banyak digunakan karena bersifat murah dan aman penggunaannya dan sangat sesuai untuk mengektraksi senyawa alkaloid, fenol, monoglikosida, dan glikosida yang terdapat pada tumbuhan [7].

\section{METODE PENELITIAN}

\begin{abstract}
Alat
Alat-alat yang digunakan yaitu spektrofotometer UV-Vis (Shimadzu UV-1700), neraca analitik (Electronic scale), ayakan mesh 60 , alat gelas kaca (Pyrex), dan rotary evaporator (Mrc).
\end{abstract}

\section{Bahan}

Bahan-bahan yang digunakan adalah pereaksi DPPH (Sigma-aldrich), etil asetat (Brataco), kuersetin (Sigmaaldrich).

\section{Prosedur}

\section{Pengambilan Bahan Uji}

Daun jambu biji merah (Psidium guajava L.) diambil dari daerah Kenten, Kecamatan Talang Kelapa, Kabupaten Banyuasin, Sumatera Selatan.

\section{Determinasi Bahan Uji}

Determinasi tanaman jambu biji merah dilakukan di Herbarium MEDANENSE (MEDA), Universitas Sumatera Utara, Medan.

\section{Pembuatan Ekstrak Daun Jambu Biji Merah}

$2000 \mathrm{~g}$ daun jambu biji dibuat simplisia, dengan mencuci bersih, dirajang, lalu disortasi basah. Kemudian dikeringkan dan ditutup dengan kain hitam. Lalu disortasi kering, dihaluskan dengan blender dan diayak dengan 
menggunakan mesh 60. $200 \mathrm{~g}$ Serbuk simplisia dimaserasi dengan pelarut etil asetat sampai semua sampel terendam. Tutup dan didiamkan selama 5 hari di tempat yang terlindungi cahaya. Selama dalam perendaman dilakukan pengadukan dan pengocokan selama 20 menit. Setelah 5 hari diserkai dengan kain flannel diperoleh hasil maserat (filtrat 1). Residu kembali direndam dengan etil asetat dan di diamkan kembali selama 2 hari, diserkai kembali didapat hasil maserat (filtrat 2). Lalu dilakukan pengulangan sampai maserat hampir tidak berwarna (dilakukan pengulangan selama 5 kali). Kemudian maserat 1 dan maserat 2 dan maserat selanjutnya digabungkan (maserat encer). Kemudian dipekatkan dengan rotary evaporator pada suhu $40^{\circ} \mathrm{C}$. Ekstrak kental yang dihasilkan ditimbang dan dihitung persentase rendemen.

\section{Uji Fitokimia Daun Jambu Biji Merah [8]}

\section{Uji Alkaloid}

$0,5 \mathrm{~g}$ ekstrak dimasukkan ke dalam gelas kimia dan ditambahkan $2 \mathrm{~mL}$ kloroform. Kemudian ditambahkan $7 \mathrm{ml}$ ammonia $10 \%, 1 \mathrm{ml}$ asam klorida $2 \mathrm{~N}$ dan $9 \mathrm{ml}$ akuades. Lalu dipanaskan di atas penangas air selama 2 menit. Lalu didinginkan dan disaring dengan kertas saring. Filtrat yang diperoleh diuji alkaloid. Diambil 3 tabung reaksi, lalu ditambahkan ke dalamnya $0,5 \mathrm{ml}$ filtrat. Pada masing-masing tabung reaksi:

a. Ditambahkan 2 tetes pereaksi Mayer menghasilkan endapan merah.

b. Ditambahkan 2 tetes pereaksi Wagner menghasilkan endapan coklat hitam.

c. Ditambahkan 2 tetes pereaksi Dragendorff menghasilkan endapan merah bata. Alkaloid positif jika terjadi endapan atau kekeruhan pada dua dari tiga percobaan di atas.

\section{Uji Flavonoid}

$1 \mathrm{~g}$ ekstrak ditambahkan serbuk magnesium secukupnya. Kemudian ditetesi 10 tetes asam klorida pekat. Adanya flavonoid dalam sampel ditandai warna hitam kemerahan pada larutan.

\section{Uji Tanin}

$1 \mathrm{~g}$ ekstrak ditambahkan dengan $10 \mathrm{~mL}$ air panas. Kemudian ditetesi besi (III) klorida. Keberadaan tanin dalam sampel ditandai warna hijau kehitaman.

\section{Uji Saponin}

$1 \mathrm{~g}$ ekstrak ditambahkan dengan $10 \mathrm{~mL}$ akuades. Kemudian dikocok kuat selama kurang lebih 1 menit dan didiamkan selama 10 menit. Keberadaan senyawa saponin dalam sampel ditandai buih stabil selama 10 menit dengan tinggi $3 \mathrm{~cm}$.

\section{Uji Steroid/Triterpenoid}

$1 \mathrm{~g}$ sampel ditambahkan dengan $2 \mathrm{~mL}$ kloroform dan dikocok. Kemudian filtrat ditambahkan asetat anhidrat dan asam sulfat pekat masing-masing 2 tetes. Jika menghasilkan warna biru atau hijau menunjukkan adanya steroid. Jika terbentuk warna merah atau ungu menunjukkan adanya triterpenoid.

\section{Pembuatan Larutan DPPH 40 ppm}

Kristal DPPH $4 \mathrm{mg}$ dilarutkan dalam metanol sampai $100 \mathrm{~mL}$.

\section{Penentuan Panjang Gelombang Maksimum DPPH}

$2 \mathrm{~mL}$ larutan DPPH $40 \mathrm{ppm}$ dalam tabung reaksi ditambahkan $2 \mathrm{~mL}$ metanol dan dikocok hingga homogen. Lalu dimasukkan ke dalam kuvet sebanyak $3 \mathrm{~mL}$ dan diukur pada panjang gelombang maksimum di $515 \mathrm{~nm}$.

\footnotetext{
Pembuatan Larutan Standar Kuersetin

10 mg kuersetin dilarutkan dengan metanol dalam labu ukur $100 \mathrm{~mL}$ sehingga diperoleh konsentrasi larutan standar kuersetin 100 ppm. Lalu dibuat variasi konsentrasi yaitu 20; 40; 60; 80;
} 
dan 100 ppm dengan cara masingmasing stok dipipet $5 ; 10 ; 15 ; 20$; dan 25 $\mathrm{mL}$. Lalu dicukupkan dengan metanol sampai volume akhir $25 \mathrm{~mL}$.

\section{Pembuatan Larutan Ekstrak Daun Jambu Biji Merah}

10 mg ekstrak daun jambu biji merah dilarutkan dengan metanol dalam labu ukur $100 \mathrm{~mL}$ untuk memperoleh konsentrasi ekstrak $100 \mathrm{ppm}$. Lalu dibuat variasi konsentrasi. yaitu 20; 40; 60; 80; dan 100 ppm dengan cara masing-masing stok dipipet $5 ; 10 ; 15$; 20; dan $25 \mathrm{~mL}$. Lalu dicukupkan dengan metanol sampai volume akhir $25 \mathrm{~mL}$.

\section{Uji Antioksidan Larutan Standar}

\section{Pengukuran Larutan Standar Kuersetin}

Larutan standar kuersetin dengan dengan variasi konsentrasi diukur serapannya dengan spektrofotometer UV-Vis. Larutan uji pembanding diambil sebanyak $2 \mathrm{~mL}$ dimasukkan ke dalam tabung reaksi dan ditambahkan DPPH 40 ppm sebanyak $2 \mathrm{~mL}$. Lalu diinkubasi dalam ruang gelap selama 30 menit. Kemudian diukur absorbansi dan dibuat kurva baku larutan standar kuersetin.

\section{Uji Antioksidan Ekstrak Daun Jambu Biji Merah}

\section{Uji Kualitatif Antioksidan Ekstrak Daun Jambu Biji}

$10 \mathrm{mg}$ ekstrak ditambahkan DPPH 40 ppm sebanyak 5 tetes dan diamati perubahan warna larutan. Adanya antioksidan menunjukkan perubahan warna larutan dari ungu menjadi kuning [9].

\section{Uji Kuantitatif Antioksidan Ekstrak Daun Jambu Biji Merah}

Larutan ekstrak dengan berbagai konsentrasi dipipet sebanyak $2 \mathrm{~mL}$. Lalu dimasukkan ke dalam tabung reaksi dan ditambahkan larutan DPPH 40 ppm sebanyak $2 \mathrm{~mL}$. Kemudian dihomogenkan dan diinkubasi dalam ruang gelap selama 30 menit. Selanjutnya diukur serapan.

\section{Analisa Data}

Nilai serapan larutan DPPH sebelum dan sesudah penambahan ekstrak tersebut dihitung sebagai persen inhibisi (\% inhibisi) dengan rumus:

$\%$ Inhibisi $=\frac{A B-A s a}{A b} \times 100 \%$

Keterangan:

A Blanko = Absorbansi tanpa sampel

A Sampel = Absorbansi mengadung sampel

Selanjutnya nilai persen inhibisi yang diperoleh dihitung nilai $I C_{50}$ dengan persamaan $y=a+b x$.

\section{HASIL DAN PEMBAHASAN}

Tanaman jambu biji merah dideterminasi untuk mengetahui identitas tanaman yang digunakan di Herbarium MEDANENSE (MEDA) Universitas Sumatera Utara, Medan. Hasil determinasi menunjukkan bahwa sampel yang digunakan merupakan Psidium guajava L. dari famili Myrtaceae.

Serbuk simplisia kering yang telah diekstraksi dengan metode maserasi dalam pelarut etil asetat diuapkan dengan rotary evaporator pada suhu $40^{\circ} \mathrm{C}$, hingga didapatkan ekstrak kental sebanyak 40 gram dengan rendemen sebesar 20\%. Maserasi merupakan metode ekstraksi cara dingin dengan melakukan perendaman sampel dalam pelarut organik yang sesuai pada suhu kamar. Pemilihan maserasi dalam ekstraksi karena memiliki banyak kelebihan seperti mudah pelaksanaannya, murah, dan tidak merusak zat aktif yang tersari di dalamnya karena dilakukan tanpa pemanasan. Pada Tabel 1 di bawah ini 
memperlihatkan hasil ekstraksi ekstrak etil asetat daun jambu biji merah.

Tabel 1. Hasil ekstraksi dari ekstrak etil asetat daun jambu biji merah (Psidium guajava L.)

\begin{tabular}{ccc}
\hline $\begin{array}{c}\text { Bobot } \\
\text { simplisia }\end{array}$ & $\begin{array}{c}\text { Bobot ekstrak } \\
\text { kental }\end{array}$ & Rendemen \\
\hline $200 \mathrm{~g}$ & $40 \mathrm{~g}$ & $20 \%$
\end{tabular}

Banyaknya senyawa aktif yang tersari dalam pelarut berpengaruh terhadap rendemen yang dihasilkan. Rendemen tinggi menunjukkan banyaknya komponen senyawa kimia yang terkandung di dalamnya [10].

Untuk mengetahui adanya senyawa aktif yang berperan sebagai antioksidan dalam daun jambu biji merah dilakukan Identifikasi metabolit sekunder. Pada Tabel 2 menunjukkan hasil identifikasi metabolit sekunder ekstrak daun jambu biji merah.

Tabel 2. Hasil uji fitokimia ekstrak daun jambu biji merah

\begin{tabular}{c|c}
\hline Uji Fitokimia & Hasil \\
\hline Alkaloid & + \\
\hline Flavonoid & + \\
\hline Tanin & + \\
\hline Saponin & + \\
\hline Steroid & - \\
\hline Triterpenoid & - \\
\hline
\end{tabular}

Keterangan:

$(+)$ : Mengandung metabolit sekunder

(-): Tidak mengandung metabolit sekunder

Dari hasil uji fitokimia, ekstrak daun jambu biji mengandung seyawa alkaloid, flavonoid, tanin, dan saponin. Sedangkan senyawa triterpenoid dan steroid tidak terkandung dalam ekstrak. Kemudian dilakukan uji antioksidan ekstrak etil asetat daun jambu biji secara kualitatif. Uji ini penting dilakukan sebagai dasar sebelum melakukan pengujian antioksidan secara kuantitatif. Senyawa antioksidan mengubah warna radikal DPPH dari ungu menjadi kuning karena kemampuannya untuk mengikat elektron bebas dari elektron yang tidak berpasangan dari senyawa radikal bebas. Dari hasil analisis yang telah dilakukan membuktikan bahwa dalam sampel yang telah diuji positif mengandung antioksidan. $\mathrm{Hal}$ ini ditandai dengan adanya perubahan warna dari ungu menjadi kuning. Penambahan DPPH pada uji kualitatif berfungsi sebagai radikal bebas yang akan bereaksi dengan antioksidan yang terdapat pada daun jambu biji merah. Perubahan warna terjadi karena adanya reaksi reduksi DPPH dari senyawa peredam radikal bebas sehingga terjadinya perubahan warna [11].

Setelah dilakukan uji antioksidan secara kualitatif kemudian dilakukan pengujian aktivitas antioksidan secara kuantitatif dilakukan dengan menggunakan metode DPPH. Pengujian ini bertujuan untuk mengetahui kemampuan ekstrak daun jambu biji merah dalam menangkap senyawa radikal atau kemampuan sebagai antioksidan. Pemilihan penggunaan metode ini karena merupakan metode yang sederhana, mudah, cepat dan peka serta memerlukan sedikit sampel untuk evaluasi aktivitas antioksidan dari senyawa bahan alam.

Prinsip pengukuran aktivitas antioksidan secara kuantitatif menggunakan metode DPPH adalah adanya perubahan intensitas warna ungu DPPH yang sebanding dengan konsentrasi larutan DPPH tersebut. Radikal bebas DPPH yang memiliki elektron yang tidak berpasangan akan memberikan warna ungu. Warna akan berubah menjadi kuning saat elektronnya berpasangan. Perubahan intensitas warna ungu ini terjadi karena adanya peredaman radikal bebas yang dihasilkan bereaksinya molekul DPPH dengan atom hidrogen yang dilepaskan oleh molekul senyawa sampel sehingga terbentuk senyawa difenil pikril hidrazil dan menyebabkan terjadinya perubahan warna DPPH dari ungu menjadi kuning 
[6]. Mekanisme reaksi dari perubahan warna tersebut terlihat pada Gambar 1.

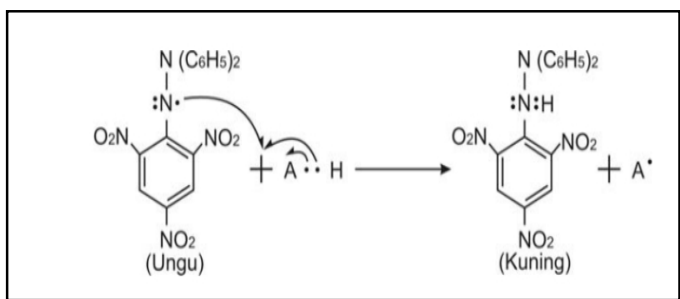

Gambar 1. Reaksi DPPH dan Antioksidan [6]

Uji antioksidan secara kuantitatif dilakukan dengan menggunakan spektrofotometer UV-Vis. Pengujian secara kuantitatif ini dilakukan untuk mengetahui absorbansi DPPH yang tersisa setelah ditambahkan ekstrak. Penurunan nilai absorbansi DPPH pada panjang gelombang maksimum $515 \mathrm{~nm}$ menunjukkan bahwa senyawa tersebut memiliki aktivitas antioksidan. Penurunan absorbansi DPPH diukur sebagai kontrol yaitu absorbansi DPPH dalam metanol tanpa penambahan sampel. Perubahan warna dari ungu menjadi kuning menandakan terjadinya penurunan absorbansi DPPH. Besarnya absorbansi DPPH berbanding terbalik dengan konsentrasi ekstrak yang ditambahkan. Dari nilai absorbansi yang diperoleh, dapat dihitung nilai persentase penghambatan radikal $\mathrm{DPPH} \quad(\% \quad$ inhibisi). Selanjutnya diperoleh kurva regresi linier dan persamaannya dengan konsentrasi sebagai sumbu $x$ dan absorbansi sebagai sumbu $y$.

Larutan standar yang digunakan sebagai kontrol positif adalah kuersetin. Kuersetin merupakan suatu aglikon flavonoid yang apabila berikatan dengan glikonnya akan menjadi glikosida. Aglikon flavonoid merupakan polifenol, sehingga mempunyai sifat kimia fenol. Dengan gugus hidroksi fenolik yang terkandung di dalamnya, membuat kuersetin memiliki daya antioksidan yang kuat. Hasil uji aktivitas antioksidan dari larutan kuersetin ditunjukkan pada Tabel 3 di bawah ini.

Tabel 3. Hasil Uji Aktivitas Antioksidan Larutan Standar Kuersetin

\begin{tabular}{|c|c|c|c|}
\hline $\begin{array}{l}\text { Konsentrasi } \\
(p p m)\end{array}$ & $\begin{array}{c}\text { Absor } \\
\text { bansi } \\
\text { Rata- } \\
\text { rata }\end{array}$ & $\begin{array}{c}\% \\
\text { Inhibisi } \\
(\%)\end{array}$ & $\begin{array}{c}\mathrm{IC}_{50} \\
(\mathrm{ppm})\end{array}$ \\
\hline 20 & 0,0288 & 89,891 & \multirow[t]{5}{*}{0,562} \\
\hline 40 & 0,0254 & 91,084 & \\
\hline 60 & 0,0229 & 91,962 & \\
\hline 80 & 0,0196 & 93,120 & \\
\hline 100 & 0,0163 & 94,278 & \\
\hline $\begin{array}{l}\text { Blanko } \\
\text { DPPH }\end{array}$ & 0,2849 & 0,0 & - \\
\hline
\end{tabular}

Peredaman radikal bebas (\% inhibisi) yang diperoleh dari Tabel 3 berbanding lurus. Semakin tinggi konsentrasi maka semakin tinggi nilai peredamannya. Dari hasil hitung $\mathrm{IC}_{50}$ menunjukkan kuersetin memiliki aktivitas antioksidan sangat kuat yaitu 0,562 ppm. Tingkat kekuatan antioksidan dengan metode DPPH dikategorikan bahwa $<50$ ppm (sangat kuat), 51-100 ppm (kuat), 101-150 ppm (sedang), dan >150 (lemah) [11].

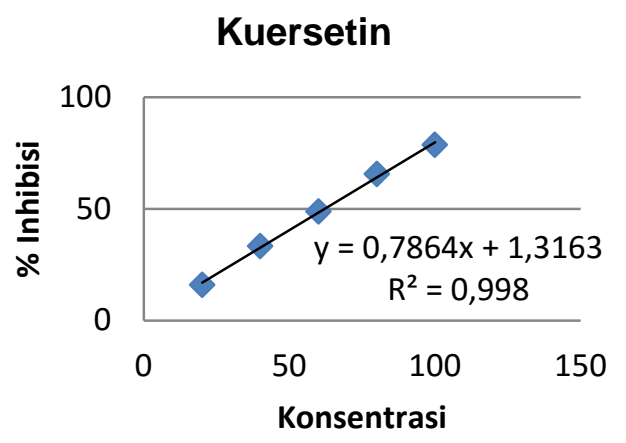

Gambar 2. Kurva baku kuersetin

Hasil persamaan regresi linear kuersetin pada gambar 2 didapatkan koefisien korelasi yang baik yaitu mendekati 1 . Persamaan regresi linear yang digunakan untuk perhitungan nilai $I_{50}$ yaitu $Y=b x+a$. Hasil nilai persamaan regresi kuersetin adalah slope (b) yang diperoleh $=0,0541 \mathrm{x}$ dan intersep $(\mathrm{a})=$ 88,821 maka persamaan regresi linear, 
$y=0,0541 x+88,82$ dengan koefisien korelasi $r=0,997$.

Hasil pengukuran absorbansi ekstrak daun jambu biji merah menunjukkan dengan peningkatan konsentrasi larutan, nilai absorbansi semakin kecil. Semakin besar konsentrasi larutan maka akan semakin banyak senyawa antioksidan yang menjadi donor hidrogen atau elektron pada radikal DPPH sehingga terjadi perubahan warna DPPH yang menyebabkan absorbansi yang dihasilkan semakin kecil.

Semakin besar konsentrasi larutan maka nilai \% inhibisi yang dihasilkan akan semakin besar. Hal ini menunjukkan adanya hubungan antara peningkatan konsentrasi dengan nilai \% inhibisi yang dihasilkan. Ekstrak etil asetat memberikan pengaruh efektifitas yang tinggi sebagai antioksidan radikal DPPH. Keefektifan antioksidan pada ekstrak etil asetat dalam menetralkan radikal bebas diduga berkaitan dengan sifat etil asetat yang semi-polar sehingga banyaknya kompenen bioaktif yang larut di dalamnya. Hasil uji aktivitas antioksidan ekstrak yang diperoleh terdapat pada Tabel 4:

Tabel 4. Hasil Uji Aktivitas Antioksidan Ekstrak Etil Asetat Daun Jambu Biji Merah

\begin{tabular}{|c|c|c|c|}
\hline $\begin{array}{c}\text { Konsentrasi } \\
(\mathrm{ppm})\end{array}$ & $\begin{array}{c}\text { Absorbansi } \\
\text { Rata-rata }\end{array}$ & $\begin{array}{c}\% \\
\text { Inhibisi }\end{array}$ & $\begin{array}{c}\mathbf{I C}_{50} \\
(\mathrm{ppm})\end{array}$ \\
\hline 20 & 0,2391 & 16,075 & \multirow[t]{5}{*}{37,39} \\
\hline 40 & 0,1898 & 33,380 & \\
\hline 60 & 0,1457 & 48,859 & \\
\hline 80 & 0,0981 & 65,569 & \\
\hline 100 & 0,0609 & 78,624 & \\
\hline $\begin{array}{c}\text { Blanko } \\
\text { DPPH }\end{array}$ & 0,2849 & 0,0 & - \\
\hline
\end{tabular}

Uji aktivitas antioksidan atau penghambatan terhadap radikal bebas menggunakan metode DPPH menunjukkan ekstrak daun jambu biji merah memiliki aktivitas antioksidan yang sangat kuat yaitu 37,39 ppm.

\section{Ekstrak Daun Jambu Biji Merah}

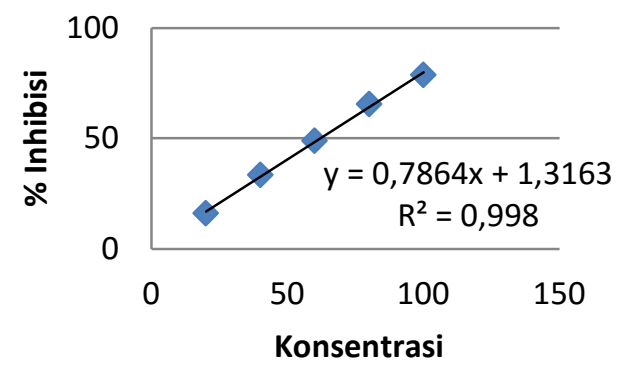

Gambar 3. Kurva baku ekstrak daun jambu biji merah

Untuk ekstrak etil asetat daun jambu biji merah diperoleh persamaan regresi linear $y=0,786 x+1,316$ dengan $r=$ 0,998 yang menyatakan bahwa adanya hubungan linear antara dua variabel $x$ dan y sehingga dapat ditentukan nilai $\mathrm{IC}_{50}$.

Berdasarkan hasil penelitian yang dilakukan dapat dilihat bahwa nilai ${ } \mathrm{C}_{50}$ kuersetin dan ekstrak etil asetat daun jambu biji merah memiliki nilai ${ } \mathrm{C}_{50}$ lebih kecil dari 50 ppm sehingga tergolong antioksidan yang sangat kuat. Pada hasil uji fitokimia, kemungkinan senyawa yang bersifat antioksidan dari ekstrak daun jambu biji adalah flavonoid, alkaloid dan saponin.

Flavonoid memiliki potensi sebagai antioksidan karena memiliki gugus hidroksil yang terikat pada karbon cincin aromatik yang dapat menangkap radikal bebas. Senyawa ini akan mendonorkan satu atom hidrogen agar radikal peroksi menjadi stabil [12]. Selain flavonoid, alkaloid juga mempunyai potensi sebagai antioksidan. Jenis alkaloid sebagai antioksidan adalah golongan indol dan quinolon yang dapat meredam radikal bebas dan menjaga sel dari pengaruh radiasi. Saponin juga dapat meredam superoksida melalui pembentukan intermediet 
hidroperoksida sehingga mencegah terjadinya kerusakan biomolekular oleh radikal bebas [13].

\section{KESIMPULAN DAN SARAN}

\section{KESIMPULAN}

Berdasarkan hasil penelitian yang dilakukan, maka ekstrak etil asetat daun jambu biji merah memiliki aktivitas antioksidan dengan kategori sangat kuat yaitu.37,39 ppm, dan golongan senyawa yang berkhasiat sebagai antioksidan adalah flavonoid, alkaloid, dan saponin.

\section{SARAN}

Diperlukan penelitian lebih lanjut dengan melakukan fraksinasi atau isolasi ekstrak daun jambi biji merah agar dapat diketahui senyawa yang berpotensi sebagai antioksidan.

\section{DAFTAR PUSTAKA}

[1] Harrizul, R., Lisa, P., dan Mahyuddin. 2010. Karakterisasi Flavonoid Antioksidan Dari Daun Jambu Biji (Psidium guajava L.). Jurnal Farmasi Higea. 2(2).

[2] Andi, E.F., Made, A., Tutik, W., dan Nancy, D.Y. 2013. Kapasitas antioksidan dan Inhibitor Alfa Glukosidase

Ekstrak Umbi Bawang Dayak. Jurnal Teknologi Dan Industri Pangan. 24(2): 161-167.

[3] Mehta, M., Saurabh., and Vandna K. 2011. Invitro Antioxidant Evaluation Of Psidium guajava Strem Extracts. International Journal Of Drug Development and Research. Vol 3. Issue 3.

[4] Bahre, T.A., \& Tchouya. 2016. Comparative study of the antioxidant activity of the total polyphenols extracted from Hibiscus sabdariffa L. Glycine max L. Merr. yellow tea and red wine through reaction with DPPH free radicals. Arab. J. Chem. 18.

[5] Adi, A.S., Nurhayati, B., dan Yuszda, K.S. 2013. Penentuan kandungan fenolik total dan aktivitas antioksidan dari rambut jagung (Zea mays L.) yang tumbuh di daerah Gorontalo. Jurnal Sainstek. Vol. 7(3).

[6] Molyneux, P. 2004. The Use of The Stable Free Radical Diphenylpicryl-hydrazyl (DPPH) for Estimating Antioxidant Activity. Journal of Science and Technology. Vol.26 (2): 211-219.

[7] Trihadi, K.A., Andi, A.,. Zainal, A., Ahmad, N. 2016. Penentuan Kadar Flavonoid Ekstrak Asetat Daun Sukun (Artocarpus altilis). Journal Pharmacy Science. Vol. 1. No. 1.

[8] Kementrian Kesehatan Republik Indoneisa 2013. Farmakope Herbal Indonesia Suplemen II. Edisi I. Jakarta: Kementrian Kesehatan RI.

[9] Nurfadillah, St.C., dan Waode, R. 2016. Analisis Antioksidan Ekstrak Etil Asetat Dari Kulit Buah Rambutan (Nephelium lappaceum) Dengan Menggunakan Metode DPPH (1Diphenyl-2-Picrylhidrazyl). Journal Al-Kimia.Vol. 4. No. 1.

[10] Sani, N.,R., Nisa, F.C., Andriani, D.R., dan Maligan, M. J. 2014. Analisis Rendemen Dan Skrining Fitokimia Ekstrak Etanol Mikroalga Laut Tetraselmis chuii. Jurnal Pangan dan Agroindustri. 2 (2):121-126.

[11] Putri A.A.S., dan Hidayati N. 2015. Uji Aktivitas Antioksidan Senyawa Fenolik Ekstrak Metanol Kulit Batang Tumbuhan 
Nyiri Batu (Xylocarpus moluccensis). Journal of Chemistry. 4(1).

[12] Dewi, N.W.O.A.C., Puspawati, N.M., Swantara, I.M.D., Asih, I.A.R.A., Rita, W.S. 2014. Aktivitas antioksidan senyawa flavonoid ekstrak etanol biji terong belanda (Solanum betaceum, syn) dalam menghambat reaksi peroksidasi lemak pada plasma darah tikus wistar. Cakra Kimia Indonesia. 2(1): 7-16.

[13] Yuhernita, dan Juniarti. 2011. Analisis senyawa metabolit sekunder dari ekstrak metanol daun Surian yang berpotensi sebagai antioksidan. Makara Sains. 15(1): 48-52. 